\title{
Multiple resistance in equine cyathostomins: a case study from military establishments in Rio Grande do Sul, Brazil
}

\author{
Múltipla resistência de ciatostomíneos de equinos: um estudo de caso em \\ estabelecimentos militares no Rio Grande do Sul, Brasil
}

Alexandra Geyer Flores ${ }^{1}$; Vanessa Osmari ${ }^{1}$; Fernanda Ramos ${ }^{1}$; Camila Balconi Marques; Denise Jaques Ramos;

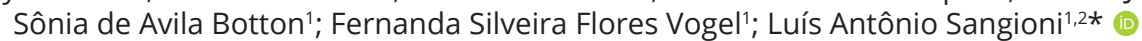

\author{
'Departamento de Medicina Veterinária Preventiva - DMVP, Centro de Ciências Rurais - CCR, Universidade Federal de Santa Maria - \\ UFSM, Santa Maria, RS, Brasil \\ ²Laboratório de Doenças Parasitárias, Departamento de Medicina Veterinária Preventiva, Centro de Ciências Rurais, Universidade \\ Federal de Santa Maria - UFSM, Santa Maria, RS, Brasil
}

\begin{abstract}
How to cite: Flores AG, Osmari V, Ramos F, Marques CB, Ramos DJ, Botton AS, et al. Multiple resistance in equine cyathostomins: a case study from military establishments in Rio Grande do Sul, Brazil. Braz J Vet Parasitol 2020; 29(3): e003820. https://doi. org/10.1590/S1984-29612020086
\end{abstract}

\begin{abstract}
Semi-intensive equine breeding system favors gastrointestinal nematode infections. The treatment of these infections is based on the use of anthelmintics. However, the inappropriate use of these drugs has led to parasitic resistance to the available active principles. The objective of this study was to evaluate the efficacy of the main classes of antiparasitic (ATP) used in control in adult and young animals, including: benzimidazoles (fenbendazole), pyrimidines (pyrantel pamoate), macrocyclic lactones (ivermectin and moxidectin), as well as the combination of active ingredients (ivermectin + pyrantel pamoate). The study was carried out in two military establishments, located in Rio Grande do Sul (RS), from January to December, 2018. The intervals between the treatments of the animals were performed from 30 to 90 days. Coproparasitological evaluations were determined by the egg count reduction in the faeces. Cyatostomine larvae were identified in pre and post-treatment cultures. The results demonstrated the multiple parasitic resistance of cyathostomins to fenbendazole, moxidectin in young animals, and to fenbendazole, pyrantel pamoate in adult animals. Thus, it is necessary to define or diagnose parasitic resistance to assist in the creation of prophylactic parasitic control, using suppressive treatment with ATP associated with integrated alternatives. The progress of parasitic resistance can be slowed.
\end{abstract}

Keywords: Equines, anthelmintic efficacy, parasitary resistance.

\begin{abstract}
Resumo
O sistema semi-intensivo de criação de equinos favorece infecções por nematoides gastrointestinais. O tratamento dessas infecções é baseado no uso de anti-helmínticos. No entanto, o uso inadequado desses medicamentos levou à resistência parasitária aos princípios ativos disponíveis. O objetivo deste estudo foi avaliar a eficácia das principais classes de antiparasitários (ATP), utilizados no controle em animais adultos e jovens, incluindo: benzimidazois (fenbendazol), pirimidinas (pamoato de pirantel), lactonas macrocíclicas (ivermectina e moxidectina), bem como a combinação de ingredientes ativos (ivermectina + pamoato de pirantel). $O$ estudo foi realizado em dois estabelecimentos militares, localizados no Rio Grande do Sul (RS), de janeiro a dezembro de 2018. Os intervalos entre os tratamentos foram realizados de 30 a 90 dias. As avaliações coproparasitológicas foram determinadas pela redução da contagem de ovos nas fezes. Foram identificadas larvas de ciatostomíneos nas coproculturas pré e pós tratamentos. Os resultados demonstraram a resistência parasitária múltipla dos ciatostomíneos ao fenbendazol, moxidectina em animais jovens, febendazole e pamoato de pirantel em animais adultos. Estabelecer o diagnóstico da resistência parasitária auxiliará na elaboração de um controle parasitário profilático, reduzindo o tratamento supressivo com ATP juntamente com alternativas de controle integrado. Dessa forma, o avanço da resistência parasitária poderá ser retardado.
\end{abstract}

Palavras-chave: Equinos, eficácia anti-helmíntica, resistência parasitária.

Received March 3, 2020. Accepted August 18, 2020.

*Corresponding author: Luís Antônio Sangioni. E-mail: lasangioni@gmail.com

This is an Open Access article distributed under the terms of the Creative Commons Attribution License, which permits unrestricted use, distribution, and reproduction in any medium, provided the original work is properly cited. 


\section{Introduction}

In Brazil, horses are being used for restoration of public order, military ceremonials, and equestrian sports, such as jumping competitions and riding competitions (Campos, 2017). In equine breeding, parasitic infections represent significant economic losses that affect animal health by causing diseases such as diarrhea and colic and also lead to weak physical conditions and performance (Barrett et al., 2004). The breeding systems of these animals are intensive, extensive, or semi-intensive, and can cause parasitic infections, especially in the first few weeks of life (Molento, 2005).

Equines are susceptible to a variety of endoparasite genera that are located in different regions of the gastrointestinal tract. The most common stomach parasites include Draschia megastoma, Habronema muscae, and Trichostrongylus axei. However, Strongyloides westeri, Strongylus spp., Parascaris equorum, and Anoplocephala spp. colonize the small intestine, and Anoplocephala spp., Oxyuris equi, Strongylus spp. and small strongyles (Cyathostominae) colonize the large intestine (Molento, 2005; Nielsen et al., 2014).

Many horses do not exhibit clinical signs of infection (i.e. they are asymptomatic carriers), but depending on the parasitic load, helminths can cause weight loss, dehydration, anemia, subcutaneous edema, pyrexia, diarrhea, colic and even animal death (Canever et al., 2013; Scare et al., 2018).

Currently, three classes of antiparasitics (ATPs) are used in horses: benzimidazoles (oxibendazole, albendazole and fenbendazole), pyrimidines (pyrantel pamoate), and macrocyclic lactones (ivermectin, abamectin and moxidectin) (Canever et al., 2013).

In breeding sites, parasitic control is usually performed suppressively, with several treatments throughout the year (Traversa et al., 2009; Von Samson-Himmelstjerna, 2012). The aim of this strategy is to administer ATPs often enough to keep the parasite load close to zero. Thus, the indiscriminate frequency in the use of ATP results in the selection of parasites resistant to the active principles, making it a major sanitary problem in equine medicine (Kaplan, 2002).

The intensive use of ATP without epidemiological basis, as well as improper dosages (sub or super dosage), will result in an increase in selection pressure of resistant parasites, initiating the development of parasitic resistance (Molento, 2005; Vera, 2014). The proportion of the parasite population that was not exposed to the drug selection process, remaining susceptible to ATP, is denominated refugia, with an increases the possibility of keeping the parasites susceptible to the active principles, if maintained at considerable levels on pasture (Molento, 2005).

The selection pressure determines the rate of resistance development, as the organisms surviving the treatment pass their genes to the next generations. By experiencing a continued selection and reproduction pressure of resistant parasites, the frequency of resistant genes will increase to the point where treatment will fail (Molento, 2005; Canever et al., 2013).

The combination of active principles may result in a synergistic parasitic effect. However, the efficacy of drug association may be low, since the high frequency of resistant alleles, at least one of the active principles may be present. Treatments with the association of ATP are recommended to avoided parasitic resistance to anthelmintics of nematodes that infect ruminants and horses (Scott et al., 2015; Ramos et al., 2016; Scare et al., 2018).

The objective of this study was to evaluate the efficacy of the main classes of antiparasitic agents used in parasitic control in adult and young horses from military environments, including: benzimidazoles (fenbendazole), pyrimidines (pyrantel pamoate) and macrocyclic lactones (ivermectin, abamectin and moxidectin), as well as the combination of two active principles ivermectin + pyrantel pamoate.

\section{Materials and Methods}

\section{Animals, samples and handling}

This study was carried out on horses from two military establishments, located in São Borja (Farm 1 - 28 44'19.8"S $55^{\circ} 35^{\prime} 07.1^{\prime \prime} \mathrm{W}$ ) and Itaara (Farm 2 - 29³1'53.6"S 5344'45.2"W) Rio Grande do Sul, Brazil. From January to December 2018, a total of 160 naturally infected horses were distributed in two animal categories: 1 ) young ( $n=50)$, aged 4 months to 2 years belonging to property 1 and 2 ) adults $(n=110)$, aged 5 to 20 years, 50 animals belonging to property 1 and 60 equines to Farm 2.

Feces samples were collected from each animal, directly from rectal ampulla by using transrectal plastic gloves, identified, conditioned in isothermal boxes, refrigerated and delivered to the laboratories where coproparasitological 
analyses were conducted. Examinations were carried out at the Parasite Diseases Laboratory (LADOPAR), at Universidade Federal de Santa Maria, RS (UFSM). Samples were processed up to 12 hours after collection. All horses were kept in semiconfining, grazing in their native field, alternating with grasses composed of Tifton 85 grass (Cynodon spp.) and Azevém (Lolium multiflorum), and supplemented with commercial rations with crude protein value between $140-160 \mathrm{~g} / \mathrm{kg}$. Water was supplied ad libitum from dams and troughs with hydraulic buoys during this study.

\section{Experimental groups}

Prior to the study, treatments were repeated every 30 to 90 days and the rotation of the active principles of anthelmintics was performed in each treatment (multiple rotation of antiparasitic drugs). The samples were collected after 30 days of the last treatment. The experimental groups of animals were selected by the result of egg counts per gram of feces (EPG), being equal to or greater than 200 EPG, divided by animal category and randomly grouped. The horses were identified by their record number (fire mark located on the left side of the pelvic limb), and animal weights were estimated by using a thoracic tape.

The animals were randomly distributed in 16 groups (G1 to G16), containing 10 equines per group. The animals were duly contained with the use of bollards and placed in containment breeches, where they received the treatments with the selected drugs. The following groups were formed: groups G1, G2, G3, G4, and G5, consisting of adult animals; groups G6, G7, G8, G9 and G10, consisting of young animals, packed in property 1; and groups $\mathrm{G} 11, \mathrm{G} 12, \mathrm{G} 13, \mathrm{G} 14, \mathrm{G} 15$ and G16, consisting of adult animals, packed at property 2. For the performance of the ATP efficacy test, fecal samples were collected from each animal 2 days before (D-2) and 14 days after treatment (D-14), according to Coles et al. (2006).

\section{Treatment}

The main ATP belonging to the parasitic classes of benzimidazoles, pyrimidines and macrocyclic lactones, as well as an association of molecules (ivermectin + pyrantel pamoate), were usually used in the control and selected for treatment and analysis of the efficacy of the active principles. The efficacy of five active principles was evaluated, as well as a combination of two of them: moxidectin (Equest ${ }^{\circledR}$ ), applied in groups G4, G7 and G14; pyrantel pamoate (Strongycid $®$ ) in groups $\mathrm{G} 3, \mathrm{G} 6$ and G13; ivermectin (Equimectin $®$ ), in groups G2, G9 and G12; fenbendazole (Fenzo| ${ }^{\circledR}$ ) in groups G5, G8 and G15; abamectin (Animax $®$ ) in the G16 group and ivermectin + pyrantel (Piraverme ${ }^{\circledR}$ ) in groups G1, G10 and G11. The drugs were administered orally at the dose and rates recommended by the manufacturer of each product, depending on the weight of the animals.

\section{Coproparasitological analyzes}

The coproparasitological technique employed in this study was a modified MacMaster (Gordon \& Whitlock, 1939), with a sensitivity of 50 EPG. So, $4 \mathrm{~g}$ of each fecal sample were homogenized and diluted in $56 \mathrm{ml}$ of saturated sugar solution, filtered and transferred to the MacMaster chamber, counting the EPG by light microscopy (100x).

The coprocultures were performed according to Coles et al. (2006). Pre- and post-treatment stool samples were used to identify the parasites in relation to gender and species and, subsequently, determine the occurrence of infection in the animals. Approximately $50 \mathrm{~g}$ of feces from each group were collected in disposable plastic containers forming a pool for each group. These samples were incubated at $28^{\circ} \mathrm{C}$, with approximately $70 \%$ relative humidity in a BOD oven for 8 days. The larvae were recovered by the Baerman method and identified according to identification keys (Bevilaqua et al., 1993). For each genus of identified parasite, the effectiveness of the treatments was estimated. All collections and tests were carried out in duplicates, being conducted in March and December 2018 , when the highest rates of translation of the parasites occurred.

\section{Analysis and interpretation of results}

The percent reduction in the number of eggs per gram of feces (R- EPG) for each group was estimated by comparing the pre-treatment EPG with the post-treatment, using the arithmetic means of the EPG counts before and after treatment, calculated by the formula: R- EPG $(\%)=100$ - (average of EPG D-14/mean of EPG D-2) x 100 (Coles et al., 1992, 2006). 
The approach used was described by Torgerson et al. (2014) and is available at University of Zurich (2018). This approach incorporates random sampling errors and aggregations between individual hosts in the treatment groups to provide $95 \%$ confidence intervals, which were taken with the percentages 2.5 and 97.5 of the resulting efficacy distribution.

The status of anthelminthic resistance was interpreted according to the recommendations of Lyndal-Murphy et al. (2014) and the Word Association for the Advancement of Veterinary Parasitology (WAAVP), the percent reduction of EPG was considered according to the upper limit of confidence (LCU) and lower (LCL) to 95\%. The treatment was considered effective when it presented the percentage of reduction of EPG and LCU at equal to or above $95 \%$ and $\mathrm{LCL}$ at equal to or above $90 \%$. Parasitic resistance was confirmed when the percentage of EPG reduction was below $90 \%$. The percentage of EPG reduction above $90 \%$ and below $95 \%$ are considered inconclusive. According to James et al. (2009) multiple resistance to parasites was considered when parasitic populations showed resistance to ATP from different chemical classes.

This study was approved by the Animal Ethics Committee of the Federal University of Santa Maria (CEUA) under the number 5023100318.

\section{Results}

The arithmetic mean and standard deviation in pre- and post-treatment, as well as the minimum and maximum EPG count for each group of both military establishments, is shown in Table 1. Cyatostomine lavas were identified in pre and post treatment cultures. The efficacy of each treatment is shown in Table 2. Considering the value of egg reduction per gram of feces (R-EPG) of less than 95\% (Lyndal-Murphy et al., 2014), it was found out that parasitic resistance occurred in the treated groups with moxidectin (52.1\% - G7), fenbendazole (1.99\% - G8), while ivermectin was inconclusive (93.6\% - G9) in Farm 1 in the young animal category. The high EPG mean observed in young animals showed a higher susceptibility to parasitism in this animal category. However, resistance to pyrantel pamoate, which had $97.6 \%$ efficacy (G6), and the combination of ivermectin + pyrantel pamoate with $99.7 \%$

Table 1. Arithmetic mean (AM) and standard error (SE) in pre (D-2) and post (D-14) treatment, minimum and maximum EPG count of each group of naturally infected horses belonging to military establishments of Rio Grande do Sul, Brazil.

\begin{tabular}{|c|c|c|c|c|c|}
\hline \multirow{2}{*}{ FARMS } & \multirow{2}{*}{ GROUP } & \multicolumn{2}{|c|}{ AM (SE) } & \multirow{2}{*}{ MIN. } & \multirow{2}{*}{ MAX. } \\
\hline & & D-2 & D-14 & & \\
\hline \multirow[t]{10}{*}{1} & G1 & 785 (466.1) & 0.0 & 200 & 1650 \\
\hline & $\mathrm{G} 2$ & $740(386.4)$ & 0.0 & 200 & 1350 \\
\hline & G3 & $800(515.3)$ & 270 (577.9) & 200 & 1800 \\
\hline & G4 & $900(351.1)$ & $85(94.4)$ & 200 & 1350 \\
\hline & G5 & 605.5 (355.7) & 835 (716.8) & 200 & 1250 \\
\hline & G6 & 770 (1328.7) & 15 (22.9) & 200 & 4500 \\
\hline & G7 & $410(87.5)$ & 190 (126.4) & 200 & 500 \\
\hline & G8 & 915 (624.5) & 1205 (625.1) & 200 & 2300 \\
\hline & G9 & $2320(859.1)$ & $145(152.3)$ & 200 & 3750 \\
\hline & G10 & 3305 (1109.8) & 0.0 & 200 & 5150 \\
\hline \multirow[t]{6}{*}{2} & G11 & $1030(442.9)$ & 0.0 & 200 & 1900 \\
\hline & G12 & $1060(488.0)$ & 0.0 & 200 & 1700 \\
\hline & G13 & $1060(531.6)$ & $115(311.8)$ & 200 & 2000 \\
\hline & G14 & $1020(443.5)$ & 0.0 & 200 & 1800 \\
\hline & G15 & $1065(390.1)$ & $810(505.4)$ & 200 & 1650 \\
\hline & G16 & 1045 (530.9) & $40(65.8)$ & 200 & 1700 \\
\hline
\end{tabular}


Table 2. Percentage reduction of EPG after each treatment and lower and higher confidence intervals in the different groups of naturally infected horses belonging to military establishments in the state of Rio Grande do Sul, Brazil.

\begin{tabular}{|c|c|c|}
\hline Farms & Group & $\begin{array}{c}\text { Reduction of EPG after treatment on each group (\%) } \\
\text { and confidence interval }\end{array}$ \\
\hline \multirow[t]{10}{*}{1} & G1- adults, ivermectin + pyrantel & $99.5(97.7-100)$ \\
\hline & G2-adults, ivermectin & $99.5(97.5-100)$ \\
\hline & G3-adults, pyrantel pamoate & $65.5(53.2-75)$ \\
\hline & G4-adults, moxidectin & $90.1(84.3-94.1)$ \\
\hline & G5-adults, fenbendazole & $2.58(0.101-11.3)$ \\
\hline & G6-young, pyrantel pamoate & $97.6(94.2-99.3)$ \\
\hline & G7-young, moxidectin & $52.1(30.9-67.8)$ \\
\hline & G8-young, fenbendazole & $1.99(0.087-9.21)$ \\
\hline & G9-young, ivermectin & $93.6(90.8-95.7)$ \\
\hline & G10-young, ivermectin + pyrantel & $99.7(99.1-100)$ \\
\hline \multirow[t]{6}{*}{2} & G11-adults, ivermectin + pyrantel & $99.7(98.2-100)$ \\
\hline & G12-adults, ivermectin & $99.7(98.2-100)$ \\
\hline & G13-adults, pyrantel pamoate & $88.7(83.2-92.7)$ \\
\hline & G14-adults, moxidectin & $98.7(96.4-99.7)$ \\
\hline & G15-adults, fenbendazole & $23.5(6.57-37.2)$ \\
\hline & G16-adults, abamectin & $98.7(96.4-99.7)$ \\
\hline
\end{tabular}

efficacy (G11 e G10), was not observed. In Farm 1, adult animals category, 99.5\% efficacy (G2 e G1) was observed in ivermectin treated animals and the combination of ivermectin + pyrantel pamoate. However, parasitic resistance occurred in the groups treated with pyrantel pamoate (65.5\% - G3), fenbendazole (2.58\% - G5) and moxidectin was inconclusive (90.1\% - G4).

Regarding the adults belonging to Farm 2, the parasitic resistance was observed in the animals treated with pyrantel pamoate and fenbendazole. On the other hand, abamectin provided $98.7 \%$ efficacy, moxidectin $98.7 \%$ efficacy and ivermectin and the combination of ivermectin + pyrantel pamoate, demonstrated $99.7 \%$ efficacy.

During pre- and post-treatment periods, the totality (100\%) of L3 larvae obtained from coprocultures from the studied properties was classified as cyathostomins.

\section{Discussion}

Our results showed a parasitic resistance of horses to benzimidazoles, which is globally reported and widely disseminated, being the first reports of benzimidazole-resistant small strongyles published in the 1960s (Drudge et al., 1963).

The parasitic resistance to fenbendazole was observed in young and adult animals of both establishments. The parasitic resistance of the genus Strongyloides to benzimidazoles was observed in several countries such as England, Canada and Brazil (Slocombe et al., 2008; Lester et al., 2013; Vera, 2014). In Chile, Von Samson-Himmelstjerna et al. (2002) reported resistance in three properties tested with fenbendazole using R- EPG with a mean efficacy of 27\% (Valdivia), 26.5\% (Riñihue) and 83.9\% (Frutillar). The low efficacy of this type of drugs was also diagnosed by Molento et al. (2008) and Canever et al. (2013) in the states of Paraná, Minas Gerais, São Paulo and Rio de Janeiro, proving that resistance to benzimidazoles is widespread in Brazil.

The resistance to benzimidazoles and pyrimidines has been reported in several countries and there are increasing reports of decreased efficacy following treatment of macrocyclic lactones. In addition, some populations of cyathostomins are carriers of resistance to multiple drugs (Peregrine et al., 2014). 
This process of resistance to benzimidazoles is controlled by a gene and the selection process is rapid, with the mutation of a single amino acid in the beta-tubulin gene in horses (Molento, 2005). The management of parasitic control in both military establishments is very similar because these units work with ATP acquisition through public commitment. Thus, ATP were administered to animals according to the availability of products purchased at establishments, regardless of drug efficacy.

Additionally, the resistance to pyrantel pamoate in the isolated formulation was observed in adult horses, being $88.7 \%$ (G13) and 65.5\% (G3) in Farm 2 and 1, respectively. However, in young animals belonging to Farm 1, efficacy of $97.6 \%$ (G6) was observed for this ATP. The resistance of this active principle has also been described in Denmark (Nielsen et al., 2006), the USA (Kaplan et al., 2014), Brazil (Molento et al., 2008), the United Kingdom, Italy and Germany (Traversa et al., 2009). In the USA, Lyons et al. (2001) reported the resistance to pyrantel pamoate after 7 subsequent years of use in a herd of ponies.

Considering that the resistance to pyrantel pamoate remained unchanged in the parasite population for decades, Gilleard \& Beech (2007) suggested that, during periods of intense selection pressure, resistant alleles in the chromosomes of parasites may arise from recurrent and/or spontaneous mutations. This event may occur after successive antiparasitic treatments (Scare et al., 2018). In the present study, the spread of ATP resistance may have occurred due to the migration of horses i.e. the traffic and constant presence of the military animals in different locations with randomized treatments.

A combination of the active principles is employed when a synergistic effect is desired. Thus, combined treatments are increasingly recommended to control anthelmintic resistance in nematodes that infect ruminants and horses (Scott et al., 2015; Ramos et al., 2016). In this study, the combination of ivermectin + pyrantel pamoate resulted in 99.5\% (G1) and 99.7\% (G11) efficacy in adult animals belonging to Farms 1 and 2, respectively. In young animals, this association resulted in $99.7 \%$ efficacy (G10).

However, the effectiveness of combination anthelmintic formulations against parasite populations may not be sustainable when these populations develop resistance to one or both of the active ingredients included in the combination (Scare et al., 2018). The appearance of ATP resistance can be attributed to the use of suppressive treatment to eliminate host parasites before completing their biological cycle, as well as the use of undue dosages of these drugs (Molento, 2005).

Several studies have reported the continued efficacy of macrocyclic lactones in R- EPG tests (Nielsen et al., 2006; Slocombe et al., 2008; Matthews, 2014), although some others have demonstrated macrocyclic lactone resistant cyathostomins (Molento et al., 2008; Traversa et al., 2009). Some populations of parasites, especially cyathostomins, are carriers of multiple resistance (Peregrine et al., 2014). In this study, 99.5\% (G2) efficacy of ivermectin on cyathostomins was observed in adult animals belonging to Farm 1, and $99.7 \%$ (G12) efficacy in animals belonging to Farm 2. However, in Farm 1, an inconclusive result was observed for ivermectin (93.6\% - G9) in the category of young animals. The results are considered inconclusive when the criteria for effectiveness or resistance have not filled.

In Brazil, the resistance of cyathostomins to macrocyclic lactones was described by Molento et al. (2008), who evaluated abamectin $2 \%$, ivermectin $1.8 \%$ and $2 \%$, moxidectin $2 \%$ in Thoroughbred equine horses and observed an efficacy of $84 \%, 5 \%, 65 \%$ and $16 \%$, respectively. Our results demonstrated the resistance to moxidectin in young animals (52.1\% - G7), and low efficacy in adult animals (90.1\% - G4) in Farm 1. Foals are considered susceptible to parasitic infection due to their still maturing immune system. We observed that the mean of EPG was higher in juveniles than in adults, showing a greater susceptibility of parasitism in this animal category. Nielsen \& Lyons (2017) established the percentage of enriched L3 (hypobiosis) in animals with 2-5 years of age in 60 to 70\%; however, the proportion of L3 in 1-year-old animals was 35\%. Resistance to moxidectin and abamectin was not found in adult animals belonging to Farm 2, with the efficacy being $98.7 \%$ (G14 and G16) for both ATP.

Although macrocyclic lactones still have high efficacy against equine nematodes and consequent reduction in EPG count, a decrease in antiparasitic action has been observed in recent years. Some studies have shown a decrease in the period of reappearance of eggs in the feces, even occurring, up to 4 weeks after treatment with these drugs in some cases (Molento et al., 2008; Lyons et al., 2011). The highest egg re-emergence period after treatment with moxidectin (12-22 weeks) is probably due to the effect against L4 larvae encysted in the intestinal mucosa (Canever et al., 2013; Nielsen \& Lyons, 2017). This short egg re-emergence period was also observed in this study after treatment with moxidectin in young animals. It was found antiparasitic drugs with reduced efficacy (inconclusive), which emphasizes the need to monitor these active principles, in order to preserve the use 
of the anthelmintic. However, Leathwick et al. (2019) indicated a consistent resistance effect of the age structure, developing faster in young animals, as observed in this study.

Resistance can be a natural event, meaning that it can happen without the application of a treatment. However, the rapid rotation of the active principles to each treatment, which is performed in military establishments, as well as the use of suppressive treatments, may be associated with cross-resistance to other active principles (Molento, 2005).

Parasitic resistance can result in significant losses in the equine breeding. Management in equine breeding should address sustainable parasitic control strategies, aiming at reducing resistance selection pressure on the parasitic population. High drug efficacy should be maintained and monitored through coproparasitological testing periodically, as demonstrated in this study. Finding the maintenance of a resting population on the property can be an auxiliary measure in parasitic control (Molento, 2005), knowing that maintaining high drug efficacy can be a major challenge.

The selective treatment, adopting the criterion of treatment based on the use of the EPG cutoff point higher than 200 for foals and 500 for adult horses, should be recommended (Molento et al., 2008). This way, the maintenance of the parasite population in refugia in the equine breeding property will be possible, thus reducing the selection pressure of parasites resistance to the drugs (Nielsen et al., 2006). However, other forms of integrated parasitological control may be possible, e.g. a consortium of animal species, rotation of pastures, selective treatment appliance, a consortium of summer crops with fodder destined to horses and periodic removal of feces from the environment (Molento, 2005).

\section{Conclusion}

Cyathostomin resistance to fenbendazole and pyrantel pamoate was observed in adult animals, whereas the resistance to moxidectin was recorded in young animals. Furthermore, low efficacy was found for moxidectin in adult animals and for ivermectin in young animals. Thus, it can be concluded that drugs that showed low efficacy in cyathostomins are not indicated for parasite control in these establishments. Moreover, it is necessary to establish an integrated parasitic control in a manner that the efficacy of the commercially available anthelmintics is preserved and the development of parasitic resistance is retarded.

\section{Acknowledgements}

The authors would like to acknowledge the military establishments for the technical support and the data supply, the team of the Laboratory of Parasitary Diseases of UFSM - LADOPAR for the accomplishment of the analysis. This study was financed in part by the Coordenação de Aperfeiçoamento de Pessoal de Nível Superior Brasil (CAPES) - Finance Code 001.

\section{References}

Barrett EJ, Farlam J, Proudman CJ. Field trial of the efficacy of a combination of ivermectin and praziquantel in horses infected with roundworms and tapeworms. Vet Rec 2004; 154(11): 323-325. http://dx.doi.org/10.1136/vr.154.11.323. PMid:15068039.

Bevilaqua CML, Rodrigues ML, Concordet D. Identification of infective larvae of some common nematode strongylids of horses. Rev Méd Vét 1993; 144(12): 989-995.

Campos CTM. O emprego do cavalo no Exército como meio de projeção do exército através do desporto equestre [trabalho de conclusão de curso]. Rio de Janeiro: Escola de Equitação do Exército; 2017.

Canever RJ, Braga PR, Boeckh A, Grycajuck M, Bier D, Molento MB. Lack of Cyathostomin sp. reduction after anthelmintic treatment in horses in Brazil. Vet Parasitol 2013; 194(1): 35-39. http://dx.doi.org/10.1016/j.vetpar.2012.12.020. PMid:23318166.

Coles GC, Bauer C, Borgsteede FH, Geerts S, Klei TR, Taylor MA, et al. World Association for the Advancement of Veterinary Parasitology (W.A.A.V.P.) methods for the detection of anthelmintic resistance in nematodes of veterinary importance. Vet Parasitol 1992; 44(1-2): 35-44. http://dx.doi.org/10.1016/0304-4017(92)90141-U. PMid:1441190.

Coles GC, Jackson F, Pomroy WE, Prichard RK, Von Samson-Himmelstjerna G, Silvestre A, et al. The detection of anthelmintic resistance in nematodes of veterinary importance. Vet Parasitol 2006; 136(3-4): 167-185. http://dx.doi.org/10.1016/j. vetpar.2005.11.019. PMid:16427201. 
Drudge JH, Szanto J, Wyant ZN, Elam G. Critical tests of thiabendazole as an anthelmintic in the horse. Am J Vet Res 1963; 24: 1217-1222. PMid:14081458.

Gilleard JS, Beech RN. Population genetics of anthelmintic resistance in parasitic nematodes. Parasitology 2007; 134(8): 11331147. http://dx.doi.org/10.1017/S0031182007000066. PMid:17608973.

Gordon HML, Whitlock HV. A new technique for counting nematode eggs is sheep faeces. J Counc Sci Ind Res 1939; $12(1)$ : 50-52.

James CE, Hudson AL, Davey MW. Drug resistance mechanisms in helminths: is it survival of the fittest? Trends Parasitol 2009; 25(7): 328-335. http://dx.doi.org/10.1016/j.pt.2009.04.004. PMid:19541539.

Kaplan RM, West EM, Norat-Collazo LM, Vargas J. A combination treatment strategy using pyrantel pamoate and oxibendazole demonstrates additive effects for controlling equine cyathostomins. Equine Vet Educ 2014; 26(9): 485-491. http://dx.doi.org/10.1111/ eve.12201.

Kaplan RM. Anthelmintic resistance in nematodes of horses. Vet Res 2002; 33(5): 491-507. http://dx.doi.org/10.1051/vetres:2002035. PMid:12387486.

Leathwick DM, Sauermann CW, Nielsen MK. Managing anthelmintic resistance in cyathostomin parasites: investigating the benefits of refugia-based strategies. Int J Parasitol Drugs Drug Resist 2019; 10: 118-124. http://dx.doi.org/10.1016/j.ijpddr.2019.08.008. PMid:31491731.

Lester HE, Spanton J, Stratford CH, Bartley DJ, Morgan ER, Hodgkinson JE, et al. Anthelmintic efficacy against cyathostomins in horses in Southern England. Vet Parasito/ 2013; 197(1-2): 189-196. http://dx.doi.org/10.1016/j.vetpar.2013.06.009. PMid:23830687.

Lyndal-Murphy M, Swain AJ, Pepper PM. Methods to determine resistance to anthelmintics when continuing larval development occurs. Vet Parasito/ 2014; 199(3-4): 191-200. http://dx.doi.org/10.1016/j.vetpar.2013.11.002. PMid:24314600.

Lyons ET, Tolliver SC, Collins SS, Ionita M, Kuzmina TA, Rossano M. Field tests demonstrating reduced activity of ivermectin and moxidectin against small stronyles in horses on 14 farms in Central Kentucky in 2007-2009. Parasitol Res 2011; 108(2): 355-360. http://dx.doi.org/10.1007/s00436-010-2068-7. PMid:20862493.

Lyons ET, Tolliver SC, Drudge JH, Collins SS, Swerczek TW. Continuance of studies on Population S benzimidazole- resistant small strongyles in a Shetland pony herd in Kentucky: effect of pyrantel pamoate (1992- 1999). Vet Parasitol 2001; 94(4): 247-256. http://dx.doi.org/10.1016/S0304-4017(00)00382-4. PMid:11137272.

Matthews JB. The future of helminth control in horses. Equine Vet J 2014; 46(1): 10-11. http://dx.doi.org/10.1111/evj.12200. PMid:24329582.

Molento MB, Antunes J, Bentes RN, Coles GC. Anthelmintic resistant nematodes in Brazilian horses. Vet Rec 2008; 162(12): 384385. http://dx.doi.org/10.1136/vr.162.12.384. PMid:18359933.

Molento MB. Resistência parasitária em helmintos de eqüídeos e propostas de manejo. Cienc Rural 2005; 35(6): $1469-1477$. http://dx.doi.org/10.1590/S0103-84782005000600041.

Nielsen MK, Haaning N, Olsen SN. Strongyle egg shedding consistency in horses on farms using selective therapy in Denmark. Vet Parasitol 2006; 135(3-4): 333-335. http://dx.doi.org/10.1016/j.vetpar.2005.09.010. PMid:16226379.

Nielsen MK, Lyons ET. Encysted cyathostomin larvae in foals - progression of stages and the effect of seasonality. Vet Parasitol 2017; 236: 108-112. http://dx.doi.org/10.1016/j.vetpar.2017.02.013. PMid:28288752.

Nielsen MK, Pfister K, Von Samson-Himmelstjerna G. Selective therapy in equine parasite control - Application and limitations. Vet Parasitol 2014; 202(3-4): 95-103. http://dx.doi.org/10.1016/j.vetpar.2014.03.020. PMid:24702770.

Peregrine AS, Molento MB, Kaplan RM, Nielsen MK. Anthelmintic resistance in important parasites of horses: does it really matter? Vet Parasitol 2014; 201(1-2): 1-8. http://dx.doi.org/10.1016/j.vetpar.2014.01.004. PMid:24485565.

Ramos F, Portella LP, Rodrigues FS, Reginato CZ, Pötter L, Cezar AS, et al. Anthelmintic resistance in gastrointestinal nematodes of beef cattle in the state of Rio Grande do Sul, Brazil. Int J Parasitol Drugs Drug Resist 2016; 6(1): 93-101. http://dx.doi.org/10.1016/j. ijpddr.2016.02.002. PMid:27054068.

Scare JA, Lyons ET, Wielgus KM, Nielsen MK. Combination deworming for the control of double-resistant cyathostomin parasites: short and longterm consequences. Vet Parasitol 2018; 251: 112-118. http://dx.doi.org/10.1016/j.vetpar.2018.01.010. PMid:29426466.

Scott I, Bishop RM, Pomroy WE. Anthelmintic resistance in equine helminth parasites - a growing issue for horse owners and veterinarians in New Zealand? N Z Vet J 2015; 63(4): 188-198. http://dx.doi.org/10.1080/00480169.2014.987840. PMid:25608588.

Slocombe JO, Coté JF, Gannes RV. The persistence of benzimidazole - resistant cyathostomes on horse farms in Ontario over 10 years and the effectiveness of ivermectin and moxidectin against these resistant strains. Can Vet J 2008; 49(1): 56-60. PMid:18320979. 
Torgerson PR, Paul M, Furrer R. Evaluating faecal egg count reduction using a specifically designed package "eggCounts" in R and a user friendly web interface. Int J Parasito/ 2014; 44(5): 299-303. http://dx.doi.org/10.1016/j.ijpara.2014.01.005. PMid:24556564.

Traversa D, Von Samson-Himmelstjerna G, Demeler J, Milillo P, Schürmann S, Barnes H, et al. Anthelmintic resistance in cyathostomin populations from horses yards in Italy, United Kingdom and Germany. Parasit Vectors 2009; 2(Suppl 2): S2. http:// dx.doi.org/10.1186/1756-3305-2-S2-S2. PMid:19778463.

University of Zurich. shiny-eggCounts [online]. 2018 [cited 2020 Mar 3]. Available from: http://shiny.math.uzh.ch/user/furrer/ shinyas/shiny-eggCounts/

Vera JHS. Resistência anti-helmíntica em equinos na Região Oeste do Estado de São Paulo [dissertação]. São Paulo: Universidade Estadual; 2014.

Von Samson-Himmelstjerna G, Von Witzendorff C, Sievers G, Schnieder T. Comparative use of faecal egg count reduction test, egg hatch assay and beta-tubulin codon 200 genotyping in small strongyles (cyathostominae) before and after benzimidazole treatment. Vet Parasitol 2002; 108(3): 227-235. http://dx.doi.org/10.1016/S0304-4017(02)00197-8. PMid:12237141.

Von Samson-Himmelstjerna G. Anthelmintic resistance in equine parasites - detection, potential clinical relevance and implications for control. Vet Parasitol 2012; 185(1): 2-8. http://dx.doi.org/10.1016/j.vetpar.2011.10.010. PMid:22100141. 